\title{
Investigation of the Total Organic Halogen Analytical Method at the Waste Sampling and Characterization Facility
}

Prepared for the U.S. Department of Energy Assistant Secretary for Environmental Management

Project Hanford Management Contractor for the

U.S. Department of Energy under Contract DE-AC06-96RL13200

\section{FLUOR。}

P.O. Box 1000

Richland, Washington 
HNF-39194

Revision 1

EDC \#: HNF-EDC-09-40380

\section{Investigation of the Total Organic Halogen Analytical Method at the Waste Sampling and Characterization Facility}

Document Type: TR

J. G. Douglas

Fluor Government Group
Program/Project: CSI

H. K. Meznarich, Ph.D.

J. R. Olsen

G. A. Ross, Ph.D.

M. Stauffer

Fluor Hanford, Inc.

Date Published

February 2009

Prepared for the U.S. Department of Energy

Assistant Secretary for Environmental Management

Project Hanford Management Contractor for the

U.S. Department of Energy under Contract DE-AC06-96RL13200

\section{FLUOR}

P.O. Box 1000

Richland, Washington
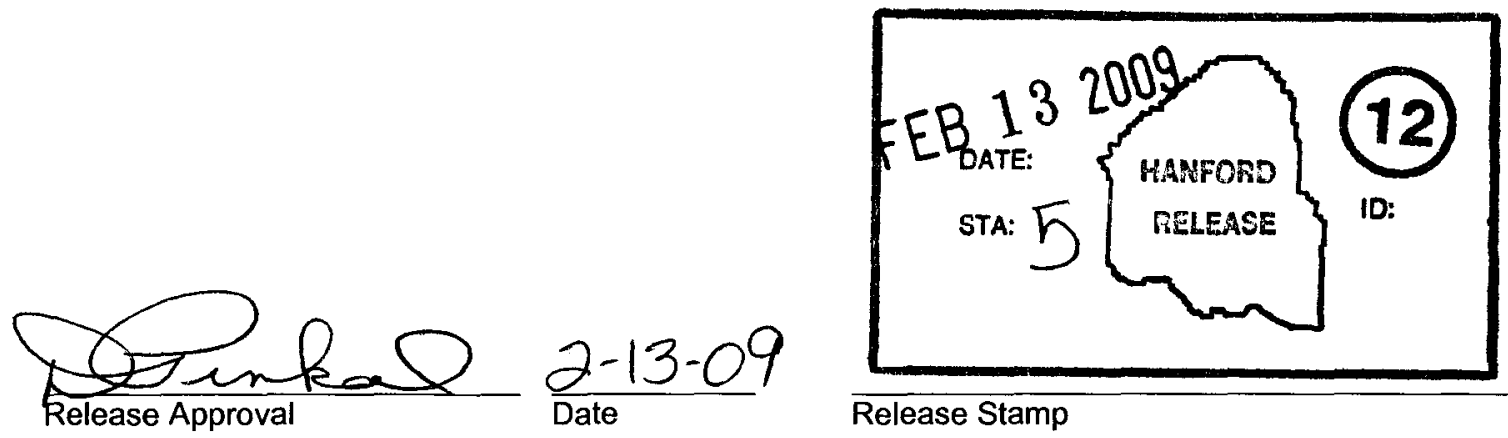

Release Stamp 
HNF-39194

Revision 1

TRADEMARK DISCLAIMER

Reference herein to any specific commercial product, process,

or service by trade name, trademark, manufacturer, or

otherwise, does not necessarily constitute or imply its

endorsement, recommendation, or favoring by the United

States Government or any agency thereof or its contractors or subcontractors.

This report has been reproduced from the best available copy.

Printed in the United States of America

Total Pages: $\quad 33$ 
RECORD OF REVISION

(2) Title

Investigation of the Total Organic Halogen Analytical Method at the Waste Sampling and Characterization Facility

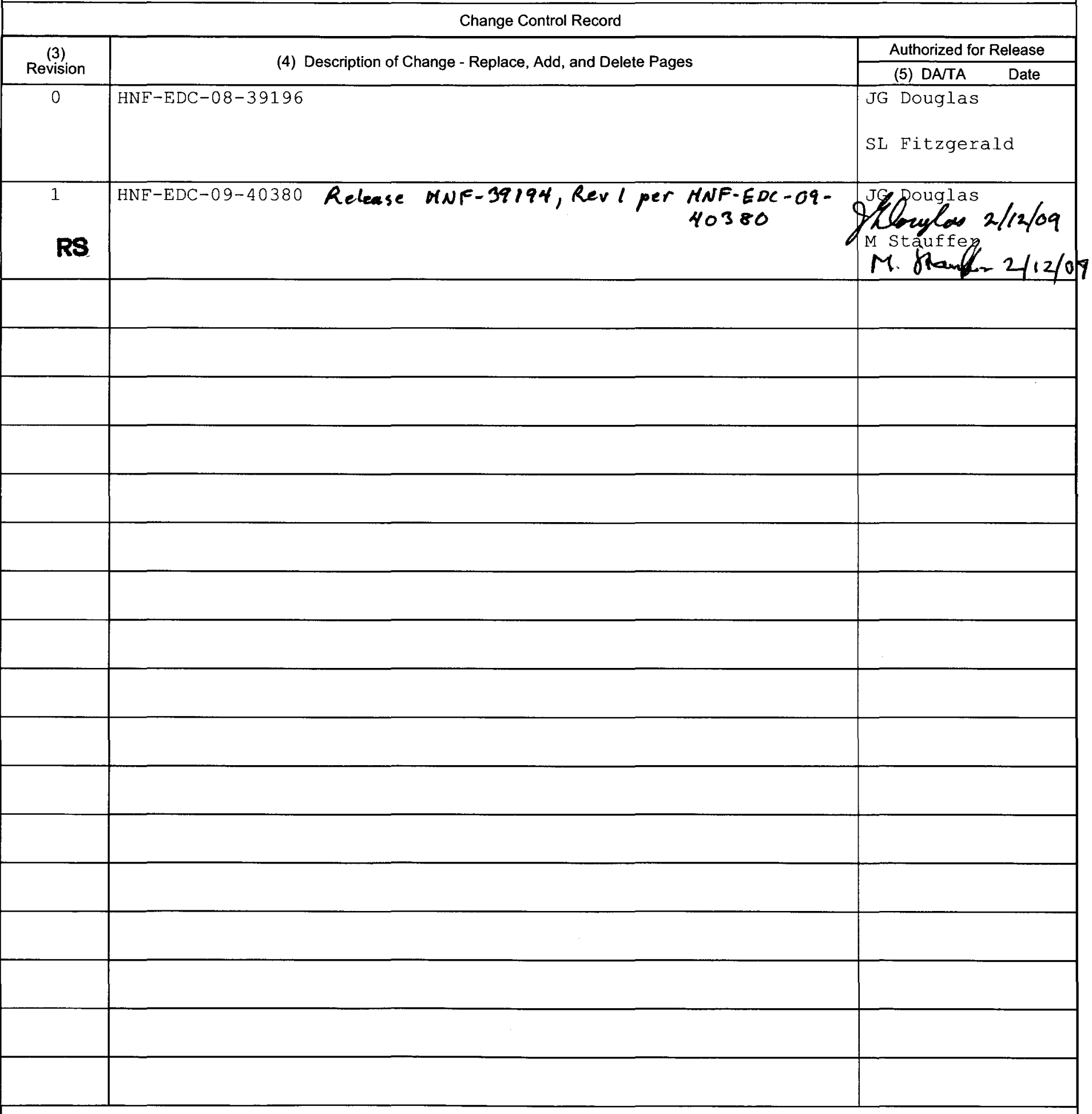




\section{HNF-39194 Revision 1}

\section{Table of Contents}

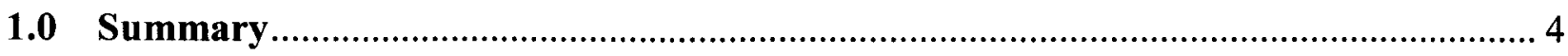

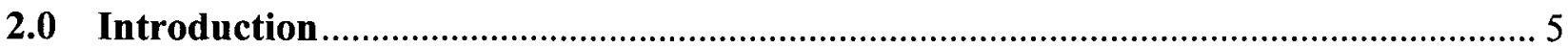

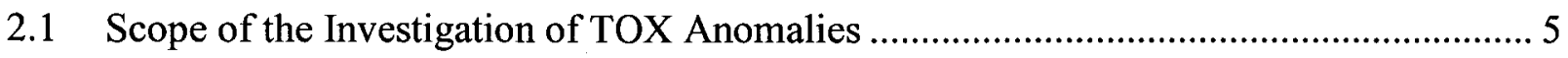

2.2 TOX Measurement Principles and Instrumentation .............................................. 5

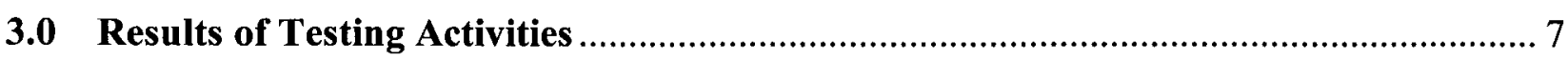

3.1 Instrument Linear Response Range ..................................................................... 7

3.1.1 TOX Linear Response Range in the Absence of Inorganic Chloride ........................ 7

3.1.2 TOX Linear Response Range in the Presence of Inorganic Chloride ........................ 9

3.1.3 TOX Linear Response Range Using Volatile Organic Halogens ........................... 12

3.2 TOX Method Detection Limit ................................................................................. 16

3.3 Sample Matrix as a Possible Cause of High TOX Recovery and High Adsorption Tube

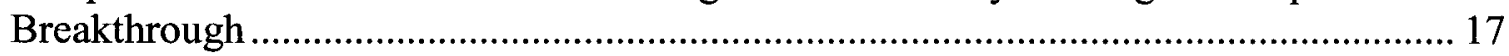

3.4 Effect of Inorganic Chloride on TOX Analyses..................................................... 18

3.5 Effect of Nitrate Wash Concentration and Volume on Removal of Inorganic Chloride 22

3.6 Effect of Purge Time During Sample Preparation on TOX Analyses .......................... 25

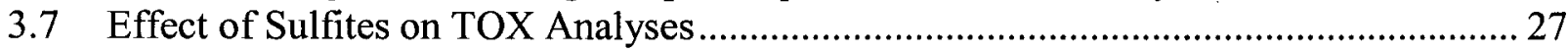

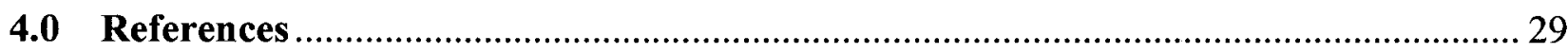




\section{HNF-39194 Revision 1}

\section{List of Tables}

Table 1. Makeup of TOX Standards for Linear Response Range Study: DI Water Matrix ......... 7

Table 2. TOX Linear Response Data: DI Water Matrix ...................................................... 8

Table 3. Makeup of TOX Standards for Linear Response Range Study: Chloride Matrix ........ 10

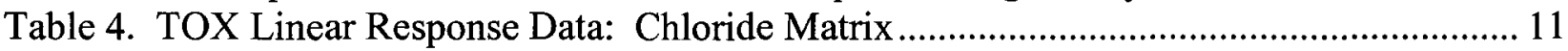

Table 5. TOX Linear Response Data: Volatile TOX in Groundwater .................................... 13

Table 6. TOX Linear Response Data: Volatile TOX in Deionized Water ............................... 15

Table 7. Method Detection Limit Determination Using 15 ppb TOX Standard ........................ 17

Table 8. Matrix Analysis Results for Four Replicate Samples.............................................. 18

Table 9. Effect of Inorganic Chloride on the Recovery of 15 ppb TOX Standards .................. 19

Table 10. Effect of Nitrate Wash Treatments on the Recovery of 15 ppb TOX Standards......... 23

Table 11. Effect of Analysis Time on TOX Analytical Results for Replicate Samples .............. 25

Table 12. Results from Sample Preparation Purge Tests....................................................... 26

Table 13. Effect of Sodium Bisulfite on TOX Results ........................................................ 28

Table 14. Comparison of TOX Results Without and With Bisulfite Treatment ....................... 28

\section{List of Figures}

Figure 1. TOX Linear Response Data: DI Water Matrix....................................................... 9

Figure 2. TOX Linear Response Data: Chloride Matrix.................................................. 11

Figure 3. TOX Linear Response Data: Volatile TOX in Groundwater .................................... 14

Figure 4. TOX Linear Response Data: Volatile TOX in Deionized Water ............................. 16

Figure 5. Effect of Inorganic Chloride on the Recovery of $15 \mathrm{ppb}$ TOX Standards .................. 20

Figure 6. Effect of Inorganic Chloride on Percent Breakthrough of $15 \mathrm{ppb}$ TOX ..................... 21

Figure 7. Effect of Nitrate Wash Treatments on the Recovery of 15 ppb TOX Standards ......... 24

\section{List of Trademarks}

\begin{tabular}{ll}
\multicolumn{1}{c}{ Trademark } & \multicolumn{1}{c}{ Owner } \\
Parafilm & American National Can Group, Inc., Greenwich, Connecticut \\
Teflon & E. I. du Pont de Nemours and Company, Wilmington, Delaware \\
Theus & Thermo Euroglas B. V., Delft, Netherlands
\end{tabular}




\section{HNF-39194 Revision 1}

\section{List of Abbreviations and Acronyms}

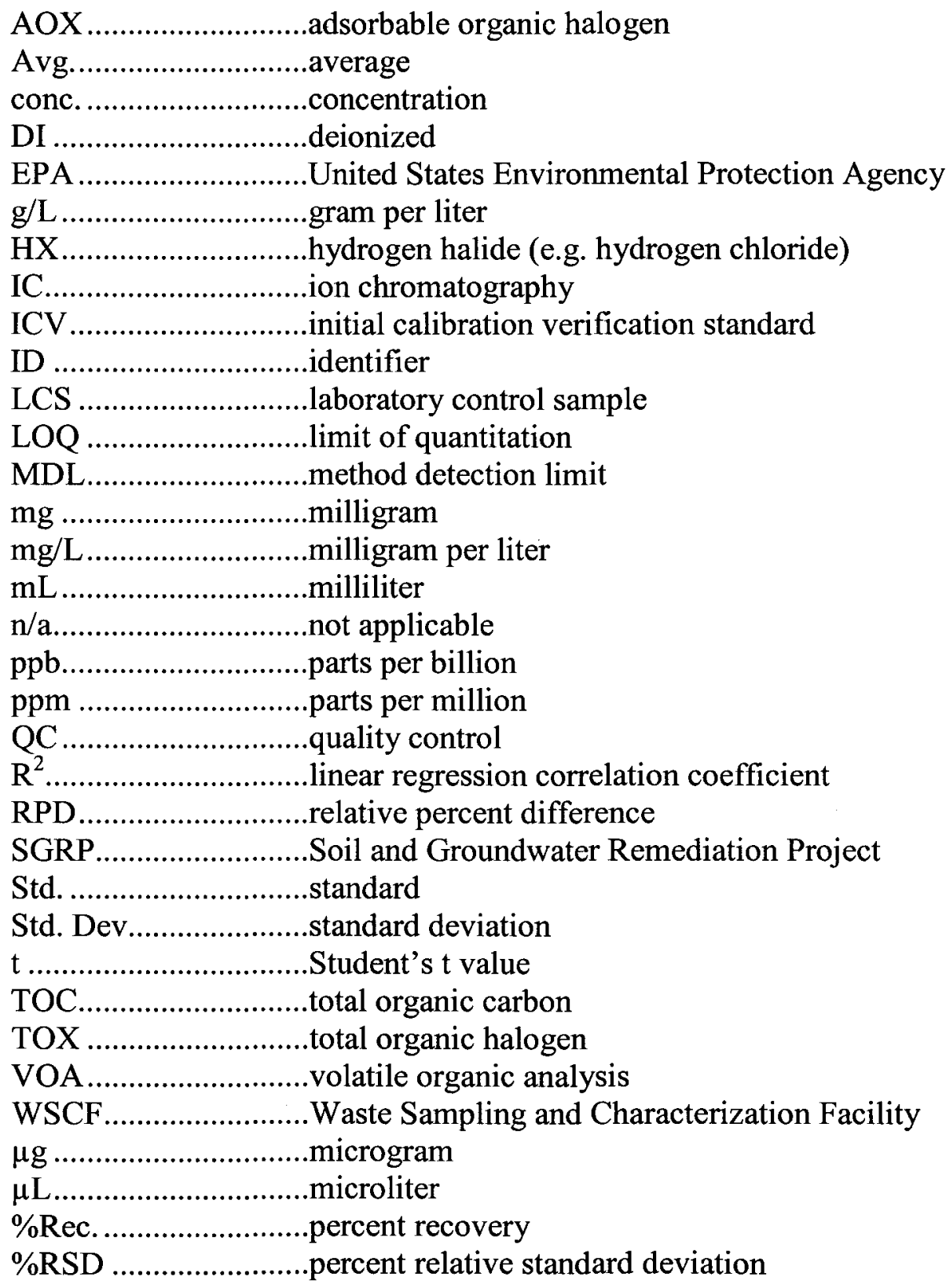




\section{HNF-39194 Revision 1}

\subsection{Summary}

Total organic halogen (TOX) is used as a parameter to screen groundwater samples at the Hanford Site. Trending is done for each groundwater well, and changes in TOX and other screening parameters can lead to costly changes in the monitoring protocol. The Waste Sampling and Characterization Facility (WSCF) analyzes groundwater samples for TOX using the United States Environmental Protection Agency (EPA) SW-846 method 9020B (EPA 1996a). Samples from the Soil and Groundwater Remediation Project (SGRP) are submitted to the WSCF for analysis without information regarding the source of the sample; each sample is in essence a "blind" sample to the laboratory. Feedback from the SGRP indicated that some of the WSCF-generated TOX data from groundwater wells had a number of outlier values based on the historical trends (Anastos 2008a). Additionally, analysts at WSCF observed inconsistent TOX results among field sample replicates. Therefore, the WSCF lab performed an investigation of the TOX analysis to determine the cause of the outlier data points.

Two causes were found that contributed to generating out-of-trend TOX data:

1. The presence of inorganic chloride in the groundwater samples: at inorganic chloride concentrations greater than about 10 parts per million (ppm), apparent TOX values increase with increasing chloride concentration. A parallel observation is the increase in apparent breakthrough of TOX from the first to the second activated-carbon adsorption tubes with increasing inorganic chloride concentration.

2. During the sample preparation step, excessive purging of the adsorption tubes with oxygen pressurization gas after sample loading may cause channeling in the activatedcarbon bed. This channeling leads to poor removal of inorganic chloride during the subsequent wash step with aqueous potassium nitrate. The presence of this residual inorganic chloride then produces erroneously high TOX values.

Changes in sample preparation were studied to more effectively remove inorganic chloride from the activated-carbon adsorption tubes. With the TOX sample preparation equipment and TOX analyzers at WSCF, the nitrate wash recommended by EPA SW-846 method 9020B was found to be inadequate to remove inorganic chloride interference. Increasing the nitrate wash concentration from 10 grams per liter $(\mathrm{g} / \mathrm{L})$ to $100 \mathrm{~g} / \mathrm{L}$ potassium nitrate and increasing the nitrate wash volume from 3 milliliters $(\mathrm{mL})$ to $10 \mathrm{~mL}$ effectively removed the inorganic chloride up to at least $100 \mathrm{ppm}$ chloride in the sample matrix. Excessive purging of the adsorption tubes during sample preparation was eliminated. These changes in sample preparation have been incorporated in the analytical procedure. The results using the revised sample preparation procedure show better agreement of TOX values both for replicate analyses of single samples and for the analysis of replicate samples acquired from the same groundwater well. Furthermore, less apparent adsorption tube breakthrough now occurs with the revised procedure. One additional modification made to sample preparation was to discontinue the treatment of groundwater samples with sodium bisulfite. Sodium bisulfite is used to remove inorganic 


\section{HNF-39194 Revision 1}

chlorine from the sample; inorganic chlorine is not expected to be a constituent in these groundwater samples.

Several other factors were also investigated as possible sources of anomalous TOX results:

- Instrument instability: examination of the history of results for TOX laboratory control samples and initial calibration verification standards indicate good long-term precision for the method and instrument. Determination of a method detection limit of $2.3 \mathrm{ppb}$ in a deionized water matrix indicates the method and instrumentation have good stability and repeatability.

- Non-linear instrument response: the instrument is shown to have good linear response from zero to 200 parts per billion (ppb) TOX. This concentration range encompasses the majority of samples received at WSCF for TOX analysis. Linear response was checked using both non-volatile TOX species (trichlorophenol) and volatile TOX species. Average recoveries of the volatile TOX species ranged between $50 \%$ and $75 \%$.

- Improper sample preservation: ion-chromatographic analysis of several samples with anomalous TOX results revealed that the samples were properly preserved with sulfuric acid and not hydrochloric acid.

\subsection{Introduction}

\subsection{Scope of the Investigation of TOX Anomalies}

The scope of the testing activities to investigate the TOX anomalies outlined in Section 1.0 was determined by the authors and from input from the SGRP customer. These testing activities included:

1. Determining the linear response range of the WSCF TOX method (WSCF 2007).

2. Determining the TOX method detection limit.

3. Investigating the effect of customer sample matrix on anomalously high TOX results.

4. Investigating the effect of inorganic chloride on TOX recovery.

5. Optimizing the potassium nitrate wash to remove residual inorganic chloride during sample preparation.

6. Evaluating the effect of adsorption tube purging and drying during sample preparation.

7. Evaluating the effect and need for bisulfite treatment of groundwater samples.

\subsection{TOX Measurement Principles and Instrumentation}

TOX analysis is comprised of two steps: sample preparation followed by analysis of the prepared samples. Sample preparation consists of the elution of an aqueous sample through two activated-carbon adsorption tubes connected in series to remove the TOX species from the aqueous matrix by adsorption onto the activated carbon. Analysis consists of pyrolyzing the carbon bed containing the adsorbed TOX species with a stream of oxygen in a furnace to release hydrogen halides (HX). The HX is swept into and trapped in an acetic acid solution where the 
HX is quantitatively titrated with silver ion. Technically, the method measures adsorbable organic halogen (AOX) as opposed to total organic halogen (TOX). We will assume that the measured AOX represents the TOX in a sample; hence the term TOX will be used throughout this document. The two adsorption tubes connected in series allows detection of breakthrough of TOX from the first to the second tube. Breakthrough can occur if the amount of TOX in the sample exceeds the capacity of the first adsorption tube to fully adsorb all the TOX in the sample. Percent breakthrough is expressed as 100 times the amount of TOX observed in the second tube divided by the sum of the TOX values in both tubes.

Sample preparation of aqueous samples is required to remove possible interferences from the samples and to transfer the organic halogens from the samples to the TOX analyzer. Possible interferences include inorganic chlorine and inorganic chloride (EPA 1996a). Inorganic chlorine is often used as a persistent biocide in municipal water supplies and may be removed by the addition of sulfite or bisulfite to the sample prior to elution of the sample through the activatedcarbon adsorption tubes. After sample elution, eluting a solution of potassium nitrate through the adsorption tubes removes the inorganic chloride. The potassium nitrate displaces and removes inorganic chloride from the activated carbon without, theoretically, displacing the organic halogens from the sample.

The sample preparation system at WSCF consists of nine sample preparation stations; with these nine stations, three samples are simultaneously prepared in triplicate. Each sample adsorption system consists of a glass sample reservoir with two adsorption tubes connected in series to the bottom of the sample reservoir. An adsorption tube consists of a glass tube containing about $40 \mathrm{mg}$ of activated carbon. The WSCF laboratory purchases adsorption tubes pre-packed with activated carbon from commercial suppliers; the tubes are shipped in sealed packages that remained sealed until sample preparation time. To adsorb organic halogens from the samples onto the activated carbon, up to $100 \mathrm{~mL}$ of aqueous sample is loaded into the sample reservoir. The reservoir is then capped and pressurized with oxygen gas to elute the sample through the adsorption tubes at approximately $3 \mathrm{~mL}$ per minute. After sample elution, the sample reservoir is loaded with a measured volume of potassium nitrate solution; this solution is then eluted through the adsorption tubes to (theoretically) remove any inorganic chloride that adsorbed onto the activated carbon.

After the final washing step, the adsorption tubes are removed from the sample reservoirs and individually loaded into the TOX analyzer autosampler. The autosampler uses a plunger to eject the activated carbon bed from each adsorption tube into a quartz boat that subsequently delivers the carbon bed into the pyrolysis furnace of the TOX analyzer. The furnace burns the sample in an oxygen atmosphere to release the organic halogens as HX gas. The gas is swept by the oxygen flow through concentrated sulfuric acid scrubbers that remove water vapor and nitrogen oxides. The gas is then swept into a titration cell where the halide ions are titrated with coulometrically generated silver ion. The titration is monitored amperometrically; the area under the titration peak is proportional to the halide ion in the original sample. The analysis is considered to be an absolute measurement, so calibration of the method with TOX standards is not required. Under computer control, the TOX analyzer can perform an analysis on an individual adsorption tube about every 12 minutes. The TOX instrumentation consists of a 


\section{HNF-39194 Revision 1}

Thermo Euroglas ECS3000 TOX analyzer equipped with an ECA1700 autosampler. The instrument is computer controlled with Thermo Theus software.

\subsection{Results of Testing Activities}

\subsection{Instrument Linear Response Range}

The linear response of the TOX analyzer was determined over the range of zero to $200 \mathrm{ppb}$ TOX without and with a background matrix of sodium chloride using standards containing 2,4,6-trichlorophenol as the TOX species. The linear response over the same range was also determined using a mixture of volatile organic halogen species in a groundwater matrix. Procedure LA-523-444 states that the TOX analyzer can titrate up to $60 \mu \mathrm{g}$ chloride from one adsorption tube combustion; however, the cell may need flushing after such a large amount (WSCF 2007). Samples containing greater than $80 \mu \mathrm{g}$ chloride can be titrated, but the cell will likely require cleaning afterwards.

\subsubsection{TOX Linear Response Range in the Absence of Inorganic Chloride}

The linear response of the TOX instrument was evaluated using 9 standards over the range of 10 to $200 \mathrm{ppb}$ TOX prepared from three different 2,4,6-trichlorophenol stock standards according to Table 1.

Table 1. Makeup of TOX Standards for Linear Response Range Study：DI Water Matrix

\begin{tabular}{|c|c|c|c|c|}
\hline $\begin{array}{l}\text { TOX Standard } \\
\text { Concentration } \\
\text { (ppb) }\end{array}$ & $\begin{array}{c}\text { Amount of } \\
\text { Stock } \\
\text { Standard }(\mu \mathrm{L})\end{array}$ & $\begin{array}{c}\text { TOX }{ }^{1} \text { Concentration } \\
\text { of Stock Standard } \\
(\text { ppm) } \\
\text { (Standard ID) }\end{array}$ & $\begin{array}{l}\text { Final Dilution } \\
\text { Volume }^{2}(\mathrm{~mL})\end{array}$ & $\begin{array}{l}\text { Total Amount } \\
\text { of TOX loaded } \\
(\mu \mathrm{g})\end{array}$ \\
\hline 10 & 2.5 & 400 (TOX080204D) & 100 & 1 \\
\hline 10 & 1 & 1000 (TOX080204B) & 100 & 1 \\
\hline 15 & 5 & 300 (TOX080204C) & 100 & 1.5 \\
\hline 30 & 10 & 300 (TOX080204C) & 100 & 3 \\
\hline 40 & 10 & 400 (TOX080204D) & 100 & 4 \\
\hline 50 & 5 & 1000 (TOX080204B) & 100 & 5 \\
\hline 100 & 10 & 1000 (TOX080204B) & 100 & 10 \\
\hline 150 & 15 & 1000 (TOX080204B) & 100 & 15 \\
\hline 200 & 20 & 1000 (TOX080204B) & 100 & 20 \\
\hline
\end{tabular}

Notes:

1 TOX provided as 2,4,6-trichlorophenol.

2 Diluent $=$ deionized water. 


\section{HNF-39194 Revision 1}

One-hundred milliliters of each standard was eluted through a single adsorption tube and then rinsed with $6 \mathrm{~mL}$ of $10 \mathrm{~g} / \mathrm{L}$ potassium nitrate solution to remove residual inorganic chloride.

The standards were analyzed in the following sequence:

- 6 nitrate rinse blanks

- $10,15,30,40$, and 50 ppb standards analyzed in triplicate

- 100 ppb standard analyzed in duplicate

- 150 and 200 ppb standard each analyzed singly

- one nitrate rinse blank

- associated method and instrument quality control (QC) samples

Table 2 and Figure 1 summarize the data obtained from the linearity study. The results show a very linear correlation over the range of 10 to $200 \mathrm{ppb}$ with a correlation coefficient of 0.998 . Standard recoveries range from $87 \%$ to $99 \%$ with an overall recovery of $90 \%$ from the slope of the regression line. Lower recoveries for the 50 through $200 \mathrm{ppb}$ standards may have been affected by the method of preparing the diluted standards: the $1000 \mathrm{ppm}$ trichlorophenol stock standard was cold from the refrigerator when injected into the deionized water diluent, and no stirring was attempted after injecting the stock standard into the diluent.

Table 2. TOX Linear Response Data: DI Water Matrix

\begin{tabular}{|c|c|c|}
\hline $\begin{array}{c}\text { Target TOX Conc. } \\
\text { (ppb) }\end{array}$ & $\begin{array}{c}\text { Recovered TOX } \\
\text { Conc. }{ }^{\mathbf{( p p b})}\end{array}$ & Percent Recovery \\
\hline 10 & 9.5 & 94.6 \\
\hline 15 & 14.9 & 99.0 \\
\hline 30 & 28.5 & 95.0 \\
\hline 40 & 38.0 & 95.0 \\
\hline 50 & 44.9 & 89.8 \\
\hline 100 & 87.9 & 87.9 \\
\hline 150 & 131.2 & 87.4 \\
\hline 200 & 184.6 & 92.3 \\
\hline
\end{tabular}

Notes:

${ }^{1}$ Does not include results from $10 \mathrm{ppb}$ standard made from the $1000 \mathrm{ppm}$ stock standard. 


\section{HNF-39194 Revision 1}

Figure 1. TOX Linear Response Data: DI Water Matrix

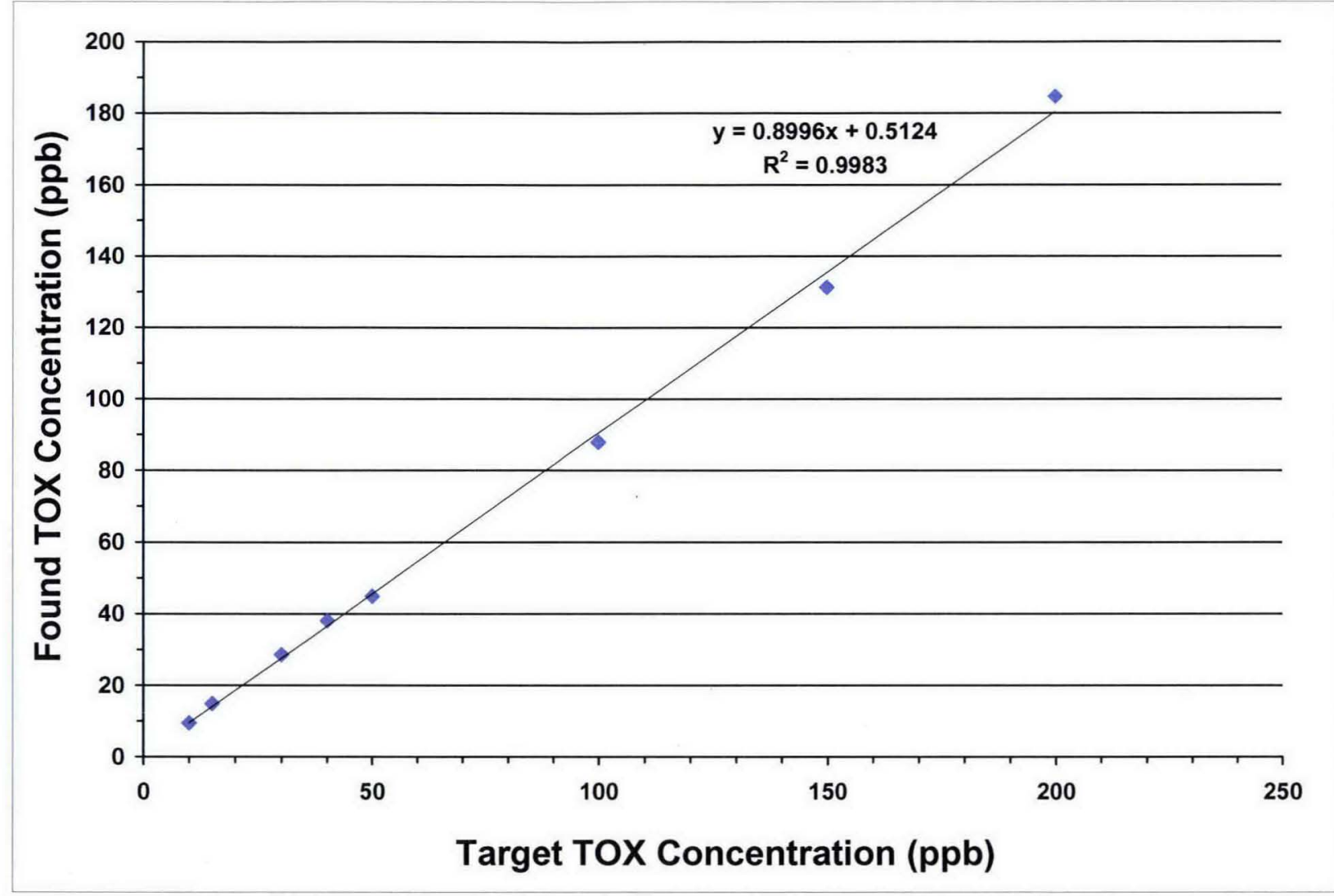

\subsubsection{TOX Linear Response Range in the Presence of Inorganic Chloride}

The initial linearity tests were performed with trichlorophenol TOX standards in a deionized water matrix. Additional experiments revealed that the presence of inorganic chloride in the sample greatly affects the TOX analysis results (see Section 3.4). Increasing the volume and concentration of the potassium nitrate wash solution to $10 \mathrm{~mL}$ and $100 \mathrm{~g} / \mathrm{L}$ potassium nitrate provided efficient removal of inorganic chloride up to a concentration of about $100 \mathrm{ppm}$ chloride. The linear response range for the method was determined again in an inorganic chloride matrix using the modified potassium nitrate wash.

The linear response of the TOX instrument was evaluated using seven TOX standards over the range of 0 to $200 \mathrm{ppb}$ TOX prepared from a $1000 \mathrm{ppm}$ 2,4,6-trichlorophenol stock standard according to Table 3 . The matrix for this study was $100 \mathrm{ppm}$ inorganic chloride (as sodium chloride) in deionized water and acidified with $0.5 \mathrm{~mL}$ concentrated sulfuric acid per liter of diluent. 
HNF-39194 Revision 1

Table 3. Makeup of TOX Standards for Linear Response Range Study: Chloride Matrix

\begin{tabular}{|c|c|c|c|c|}
\hline $\begin{array}{c}\text { TOX Standard } \\
\text { Concentration } \\
(p p b)\end{array}$ & $\begin{array}{l}\text { Amount of } \\
\text { Stock } \\
\text { Standard } \\
(\mu \mathrm{L})\end{array}$ & $\begin{array}{c}\text { TOX }{ }^{1} \text { Concentration } \\
\text { of Stock Standard } \\
\text { (ppm) } \\
\text { (Standard ID) }\end{array}$ & $\begin{array}{c}\text { Final Dilution } \\
\text { Volume }^{2} \\
(\mathrm{~mL})\end{array}$ & $\begin{array}{l}\text { Total Amount } \\
\text { of TOX } \\
\text { loaded }^{3} \\
(\mu \mathrm{g})\end{array}$ \\
\hline 0 & 0 & $\mathrm{n} / \mathrm{a}$ & 250 & 0 \\
\hline 5 & 1.25 & 1000 (TOX080204B) & 250 & 0.5 \\
\hline 10 & 2.5 & 1000 (TOX080204B) & 250 & 1 \\
\hline 30 & 7.5 & 1000 (TOX080204B) & 250 & 3 \\
\hline 50 & 12.5 & 1000 (TOX080204B) & 250 & 5 \\
\hline 100 & 25 & 1000 (TOX080204B) & 250 & 10 \\
\hline 200 & 50 & 1000 (TOX080204B) & 250 & 20 \\
\hline
\end{tabular}

Notes:

1 TOX provided as 2,4,6-trichlorophenol.

${ }^{2}$ Diluent $=100 \mathrm{ppm}$ chloride (as sodium chloride) acidified with $0.5 \mathrm{~mL}$ conc. sulfuric acid per liter of diluent.

3 Based on a $100-\mathrm{mL}$ sample aliquot.

One-hundred milliliters of each standard was adsorbed onto two adsorption tubes in series and then rinsed with $10 \mathrm{~mL}$ of $100 \mathrm{~g} / \mathrm{L}$ potassium nitrate solution to remove residual inorganic chloride.

The standards were analyzed in the following sequence:

- 6 nitrate rinse blanks

- $100 \mathrm{~mL}$ of each standard analyzed in duplicate in reverse order: $200,100,50,30,10,5$, and $0 \mathrm{ppb}$

- LCS standard analyzed every 8-12 samples to verify instrument performance

- 10 ppb standard analyzed an additional five times (for a total of seven measurements) to allow calculation of the method detection limit in a chloride matrix

Table 4 and Figure 2 summarize the data obtained from this linearity study. The results show a very linear correlation over the range of 0 to $200 \mathrm{ppb}$ with a correlation coefficient of 0.998 . Corrected recoveries range from $50 \%$ to $106 \%$ with an overall recovery of $91 \%$ from the slope of the regression line; corrected recoveries were generated by subtracting the response of the $0 \mathrm{ppm}$ TOX standard from the responses of the remaining TOX standards (see Table 4). The lowest recovery was for the $5 \mathrm{ppb}$ standard. The new washing process with $10 \mathrm{~mL}$ of $100 \mathrm{~g} / \mathrm{L}$ potassium nitrate solution appears to effectively remove up to $100 \mathrm{ppm}$ inorganic chloride in a $100-\mathrm{mL}$ sample aliquot. A method detection limit of $5.1 \mathrm{ppb}$ was calculated based on the seven measurements of the $10 \mathrm{ppb}$ TOX standard in the $100 \mathrm{ppm}$ inorganic chloride matrix. 
Table 4. TOX Linear Response Data: Chloride Matrix ${ }^{1}$

\begin{tabular}{|c|c|c|c|c|}
\hline $\begin{array}{c}\text { Target TOX } \\
\text { Conc. (ppb) }\end{array}$ & $\begin{array}{c}\text { Uncorrected } \\
\text { Recovered TOX } \\
\text { Conc. (ppb) }\end{array}$ & $\begin{array}{c}\text { Uncorrected } \\
\text { Percent } \\
\text { Recovery }\end{array}$ & $\begin{array}{c}\text { Corrected } \\
\text { Recovered } \\
\text { TOX Conc. } \\
\text { (ppb) }\end{array}$ & $\begin{array}{c}\text { Corrected } \\
\text { Percent } \\
\text { Recovery }\end{array}$ \\
\hline 0 & 4.96 & $\mathrm{n} / \mathrm{a}$ & 0 & $\mathrm{n} / \mathbf{a}$ \\
\hline 5 & 7.48 & 149.6 & 2.52 & 50.4 \\
\hline 10 & 14.37 & 143.7 & 9.41 & 94.1 \\
\hline 30 & 36.85 & 122.8 & 31.89 & 106.3 \\
\hline 50 & 56.30 & 112.6 & 51.34 & 102.7 \\
\hline 100 & 101.67 & 101.7 & 96.71 & 96.7 \\
\hline 200 & 186.60 & 93.3 & 181.64 & 90.8 \\
\hline
\end{tabular}

Notes:

${ }^{1}$ Matrix $=100 \mathrm{ppm}$ chloride (as sodium chloride) in deionized water acidified with $0.5 \mathrm{~mL}$ conc. sulfuric acid per liter of solution.

2 Corrected by subtracting the $0 \mathrm{ppb}$ TOX value $(4.96 \mathrm{ppb})$.

Figure 2. TOX Linear Response Data: Chloride Matrix

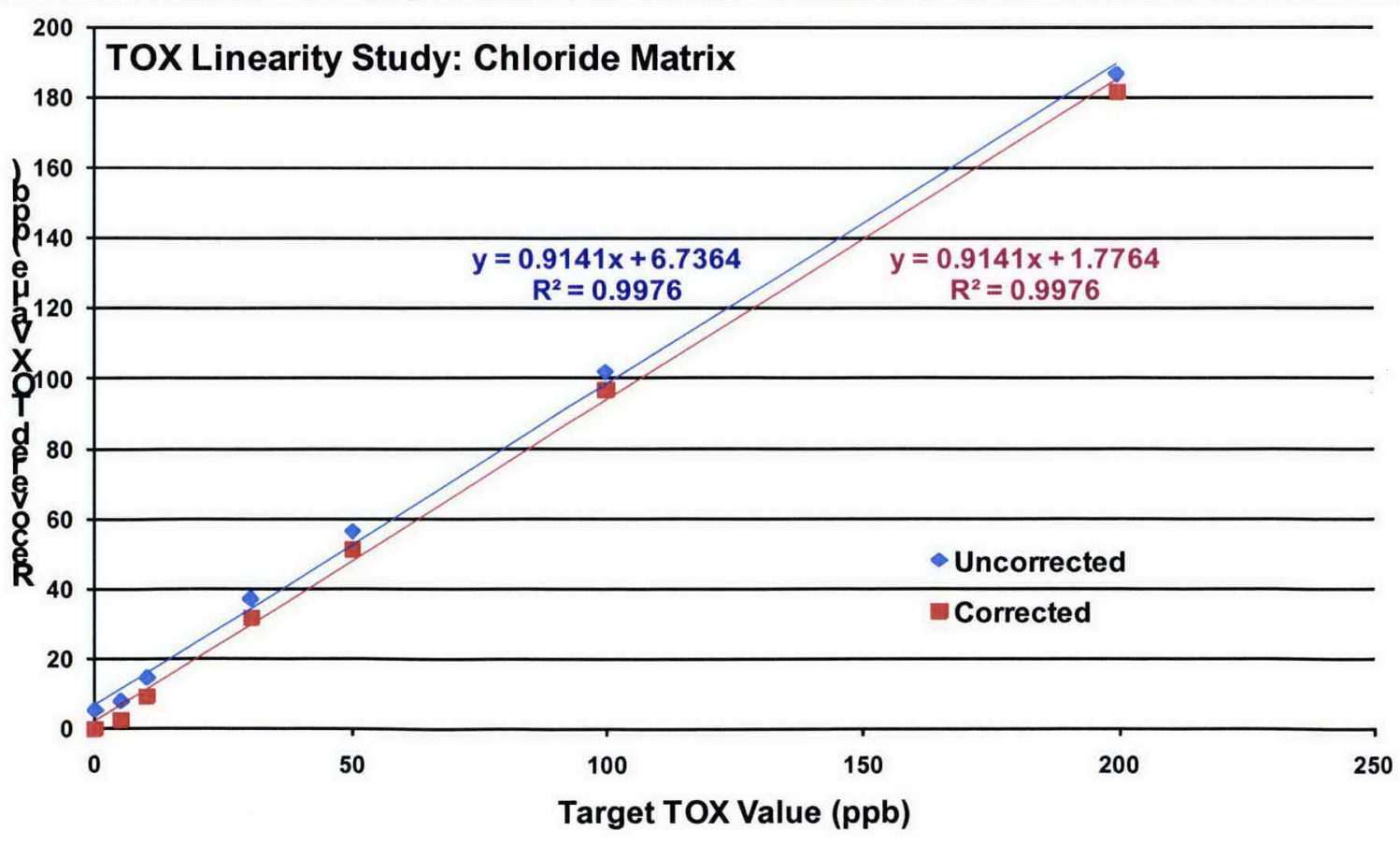




\subsubsection{TOX Linear Response Range Using Volatile Organic Halogens}

Two linear response studies were performed using volatile TOX species instead of the much less volatile trichlorophenol. The first volatile TOX study was performed using a commercial volatile TOX standard in a groundwater matrix. The second study used an in-house-prepared carbon tetrachloride standard in a deionized water matrix; this second study was performed twice.

\subsubsection{Linearity Study Using a Commercial Volatile Organic Halogen Standard in a Groundwater Matrix}

For the first volatile TOX study, a 500 ppm stock TOX standard was diluted from a commercially available standard that contained equal amounts by weight of carbon tetrachloride, tetrachloroethylene, trichloroethene, methylene chloride, and chloroform diluted in methanol. The stock standard was stored in a Teflon-lined septum-cap vial in a freezer and was warmed to room temperature prior to makeup of the aqueous standards in the groundwater matrix. The SGRP supplied the groundwater used as the diluent for the working standards. Nine working standards over the range of 10 to $200 \mathrm{ppb}$ TOX were prepared in 250 -mL volumetric flasks; each standard was acidified with $0.125 \mathrm{~mL}$ concentrated sulfuric acid. To minimize loss of the volatile species from the working standards, minimal mixing of the standards in the $250-\mathrm{mL}$ volumetric flasks was used, the flasks were sealed with Parafilm prior to analysis, and the standards were analyzed within 36 hours of preparation. A $100-\mathrm{mL}$ aliquot of each standard was analyzed in duplicate along with trichlorophenol QC standards using procedure LA-523-444 (WSCF 2007). After elution of each sample through two adsorption tubes in series, the tubes were washed to remove residual inorganic chloride with $10 \mathrm{~mL}$ of $100 \mathrm{~g} / \mathrm{L}$ potassium nitrate solution followed by $2 \mathrm{~mL}$ deionized water.

Table 5 and Figure 3 summarize the data obtained from this linearity study. The results show a linear correlation over the range of 0 to $200 \mathrm{ppb}$ with a correlation coefficient of 0.997 . Corrected recoveries range from $44 \%$ to $60 \%$ with an average corrected recovery of $54 \%$; corrected recoveries were generated by subtracting the response of the $0 \mathrm{ppm}$ TOX standard from the responses of the remaining TOX standards (see Table 5). The $40 \mathrm{ppb}$ standard exhibited such poor recovery that it was dropped from the data set. After the $40 \mathrm{ppb}$ standard, the $30 \mathrm{ppb}$ standard exhibited the poorest recovery at $44 \%$.

The poorer recoveries observed in these results compared to those results obtained in Sections 3.1.1 and 3.1.2 may have several causes:

- The 500 ppm volatile TOX stock standard was made on a volume, not mass, basis. If the volumetric measurements were not sufficiently accurate, the actual TOX concentration of the 500 ppm stock standard may have been less than 500 ppm. 
- The diluted standards were prepared in volumetric flasks with some headspace. The possibility exists that a portion of the volatile TOX species may have escaped to the headspace prior to analysis.

- Some loss of the volatile TOX species may have occurred during sample preparation. Such losses are not as likely for the much less volatile trichlorophenol standards.

Table 5. TOX Linear Response Data: Volatile TOX in Groundwater ${ }^{1}$

\begin{tabular}{|c|c|c|c|c|}
\hline $\begin{array}{c}\text { Target TOX } \\
\text { Conc. (ppb) }\end{array}$ & $\begin{array}{c}\text { Uncorrected } \\
\text { Recovered TOX } \\
\text { Conc. (ppb) }\end{array}$ & $\begin{array}{c}\text { Uncorrected } \\
\text { Percent } \\
\text { Recovery }\end{array}$ & $\begin{array}{c}\text { Corrected } \\
\text { Recovered } \\
\text { TOX Conc. } \\
\text { (ppb) }\end{array}$ & $\begin{array}{c}\text { Corrected } \\
\text { Percent } \\
\text { Recovery }\end{array}$ \\
\hline 0 & 5.46 & $\mathrm{n} / \mathrm{a}$ & 0 & $\mathrm{n} / \mathrm{a}$ \\
\hline 10 & 11.43 & $114.3 \%$ & 5.97 & $59.7 \%$ \\
\hline 20 & 15.00 & $75.0 \%$ & 9.54 & $47.7 \%$ \\
\hline 30 & 18.75 & $62.5 \%$ & 13.29 & $44.3 \%$ \\
\hline $40^{3}$ & $\mathrm{n} / \mathrm{a}$ & $\mathrm{n} / \mathrm{a}$ & $\mathrm{n} / \mathrm{a}$ & $\mathrm{n} / \mathrm{a}$ \\
\hline 50 & 32.78 & $65.6 \%$ & 27.32 & $54.6 \%$ \\
\hline 100 & 58.90 & $58.9 \%$ & 53.44 & $53.4 \%$ \\
\hline 150 & 91.05 & $60.7 \%$ & 85.59 & $57.1 \%$ \\
\hline 200 & 125.04 & $62.5 \%$ & 119.58 & $59.8 \%$ \\
\hline
\end{tabular}

Notes:

${ }^{1}$ Matrix $=$ groundwater supplied by SGRP acidified with $0.125 \mathrm{~mL}$ conc. sulfuric acid per $250 \mathrm{~mL}$ of solution.

${ }^{2}$ Corrected by subtracting the $0 \mathrm{ppb}$ TOX value ( $5.46 \mathrm{ppb}$ ).

${ }^{3}$ Recovery of the $40 \mathrm{ppb}$ standard was so poor that it was dropped from the data set. 
Figure 3. TOX Linear Response Data: Volatile TOX in Groundwater

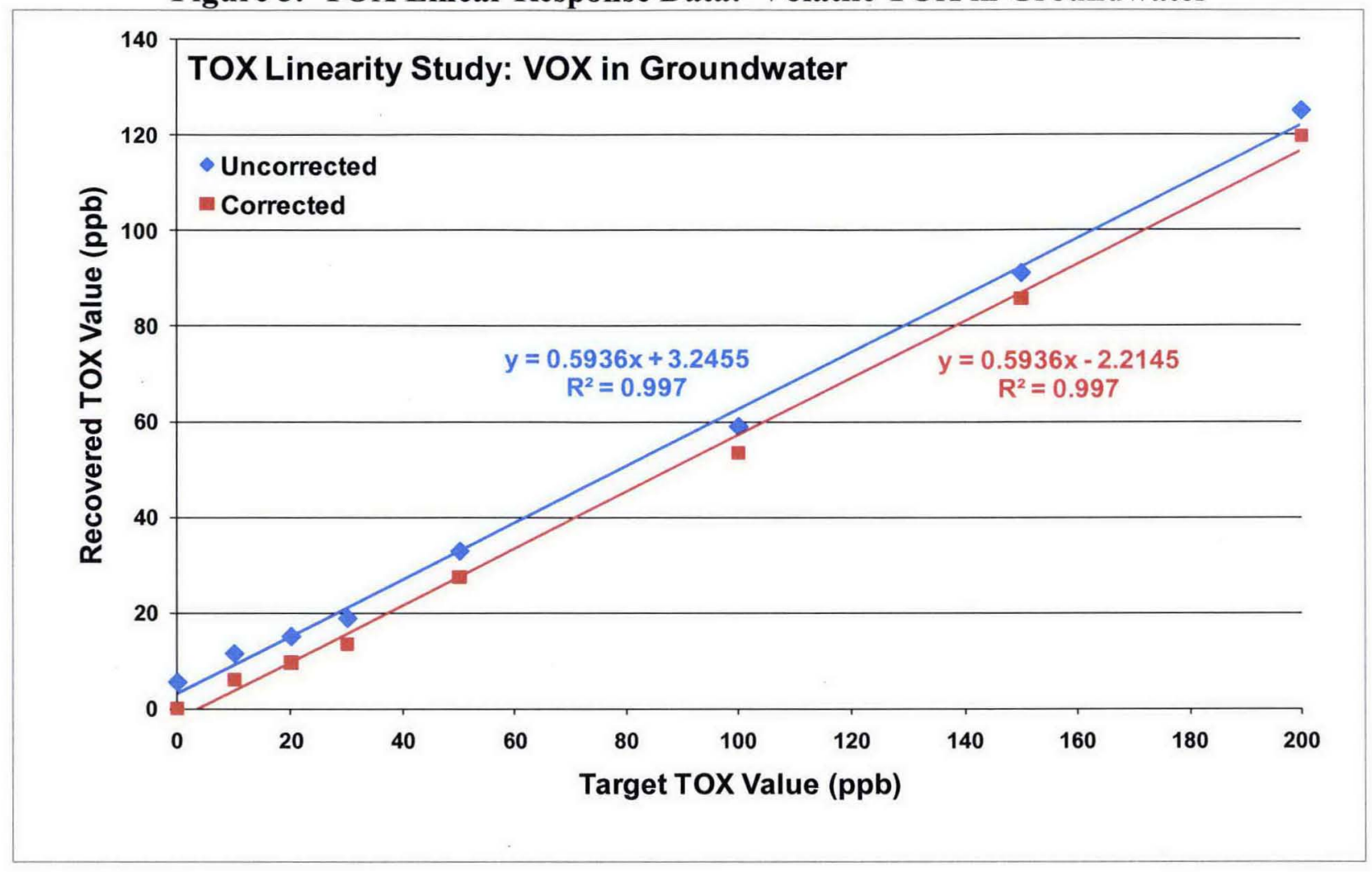

\subsubsection{Linearity Study Using a Carbon Tetrachloride Standard in Deionized Water}

The second volatile TOX study used an in-house-prepared nominal 500 ppm volatile TOX stock standard consisting of carbon tetrachloride in methanol. This study was performed twice using the same stock standard both times; the first study was performed on December 8, 2008, and the second study on January 20, 2009. The volatile TOX stock standard was prepared by diluting $5.94 \mathrm{mg}$ of standards-grade carbon tetrachloride into $9.5571 \mathrm{~g}$ of reagent-grade methanol; this yielded a standard value of $573 \mu \mathrm{g} / \mathrm{g}$ TOX or $453 \mu \mathrm{g} / \mathrm{mL}$ TOX. The stock standard was stored in a brown-glass vial capped with a Teflon-lined cap in a freezer and was warmed to room temperature prior to makeup of the aqueous standards in deionized water. To check the calculated concentration of the carbon tetrachloride stock TOX standard, six adsorption tubes were directly injected with $10 \mu \mathrm{L}$ of the stock TOX standard and pyrolyzed. The average result for the six tubes was $461 \mu \mathrm{g} / \mathrm{mL}$ for an average recovery of $102 \%$.

Five working standards over the nominal range of 25 to $200 \mathrm{ppb}$ TOX were prepared, each in duplicate. Each working standard was prepared by adding $100 \mathrm{~mL}$ of deionized water to the sample reservoir of the TOX sample preparation work station. For the December 8 study, no sulfuric acid was added to the deionized water; for the January 20 study, the deionized water was acidified with a drop of concentrated sulfuric acid. The appropriate volume of the $453 \mu \mathrm{g} / \mathrm{mL}$ volatile TOX stock standard was then syringed into the water, and the sample reservoir was immediately capped to avoid loss of carbon tetrachloride from the sample. Duplicate working 


\section{HNF-39194 Revision 1}

standards at each concentration were prepared and analyzed along with trichlorophenol QC standards using procedure LA-523-444 (WSCF 2007). For the working standards, two adsorption tubes in series were used to trap TOX. After elution of each sample through the adsorption tubes, the tubes were washed with $10 \mathrm{~mL}$ of $100 \mathrm{~g} / \mathrm{L}$ potassium nitrate solution followed by $2 \mathrm{~mL}$ deionized water to remove residual inorganic chloride.

Table 6 and Figure 4 show the results of these two linearity tests using the carbon tetrachloridebased standards. The results show a remarkably reproducible linear response over the range of 23 to $181 \mathrm{ppb}$ with a minimum correlation coefficient of 0.96 . Recoveries range from $55 \%$ to $100 \%$ with an average recovery of about $74 \%$; recoveries tend to increase as the volatile TOX concentration increases. These results are somewhat greater than the $54 \%$ corrected recovery observed with the volatile TOX species in the groundwater matrix study. This difference is likely due to the way the working standards were prepared. For the initial study using the commercial volatile TOX standard in groundwater, the working standards were diluted in volumetric flasks about 36 hours prior to analysis. For the carbon tetrachloride volatile TOX study, the working standards were prepared directly in the sample preparation reservoirs and immediately eluted through the adsorption tubes. The recovery results from the groundwatermatrix volatile TOX study and the carbon tetrachloride TOX study indicate that recoveries are likely to range between $50 \%$ and $75 \%$ for samples containing volatile TOX species.

Table 6. TOX Linear Response Data: Volatile TOX in Deionized Water

\begin{tabular}{|c|c|c|c|c|c|c|}
\hline \multirow[b]{2}{*}{$\begin{array}{l}\text { Standard } \\
\text { Number }\end{array}$} & \multirow{2}{*}{$\begin{array}{c}\mu \mathrm{L} \text { TOX } \\
\text { Standard }{ }^{1} \\
\text { per } \\
100 \mathrm{~mL}\end{array}$} & \multirow{2}{*}{$\begin{array}{l}\text { Actual } \\
\text { TOX } \\
\text { conc. } \\
\text { (ppb) }\end{array}$} & \multicolumn{2}{|c|}{ 12-08-2008 Study ${ }^{2}$} & \multicolumn{2}{|c|}{$01-20-2009$ Study $^{3}$} \\
\hline & & & $\begin{array}{c}\text { Found } \\
\text { TOX conc. } \\
\text { (ppb) }\end{array}$ & $\begin{array}{l}\text { Percent } \\
\text { Recovery }\end{array}$ & $\begin{array}{c}\text { Found } \\
\text { TOX conc. } \\
\text { (ppb) }\end{array}$ & $\begin{array}{c}\text { Percent } \\
\text { Recovery }\end{array}$ \\
\hline VOA025 & 5 & 23 & 13 & $57 \%$ & 14 & $61 \%$ \\
\hline VOA050 & 10 & 45 & 26 & $57 \%$ & 25 & $55 \%$ \\
\hline VOA100 & 20 & 91 & 68 & $75 \%$ & 72 & $79 \%$ \\
\hline VOA150 & 30 & 136 & 102 & $75 \%$ & 113 & $83 \%$ \\
\hline VOA200 & 40 & 181 & 181 & $100 \%$ & $169^{5}$ & $93 \%$ \\
\hline & & & Average: & $73 \%$ & Average: & $74 \%$ \\
\hline
\end{tabular}

Notes:

${ }^{1}$ Standard $=453 \mu \mathrm{g} / \mathrm{mL}$ TOX standard consisting of $5.94 \mathrm{mg}$ carbon tetrachloride dissolved in $9.5571 \mathrm{~g}$ of reagent-grade methanol.

${ }^{2}$ Matrix $=100 \mathrm{~mL}$ deionized water; no sulfuric acid was added.

${ }^{3}$ Matrix $=100 \mathrm{~mL}$ deionized water acidified with one drop of concentrated sulfuric acid.

${ }^{4}$ These results are the average of two replicates.

${ }^{5}$ One of these two replicate sample results was not included because of extremely low recovery. 
HNF-39194 Revision 1

Figure 4. TOX Linear Response Data: Volatile TOX in Deionized Water

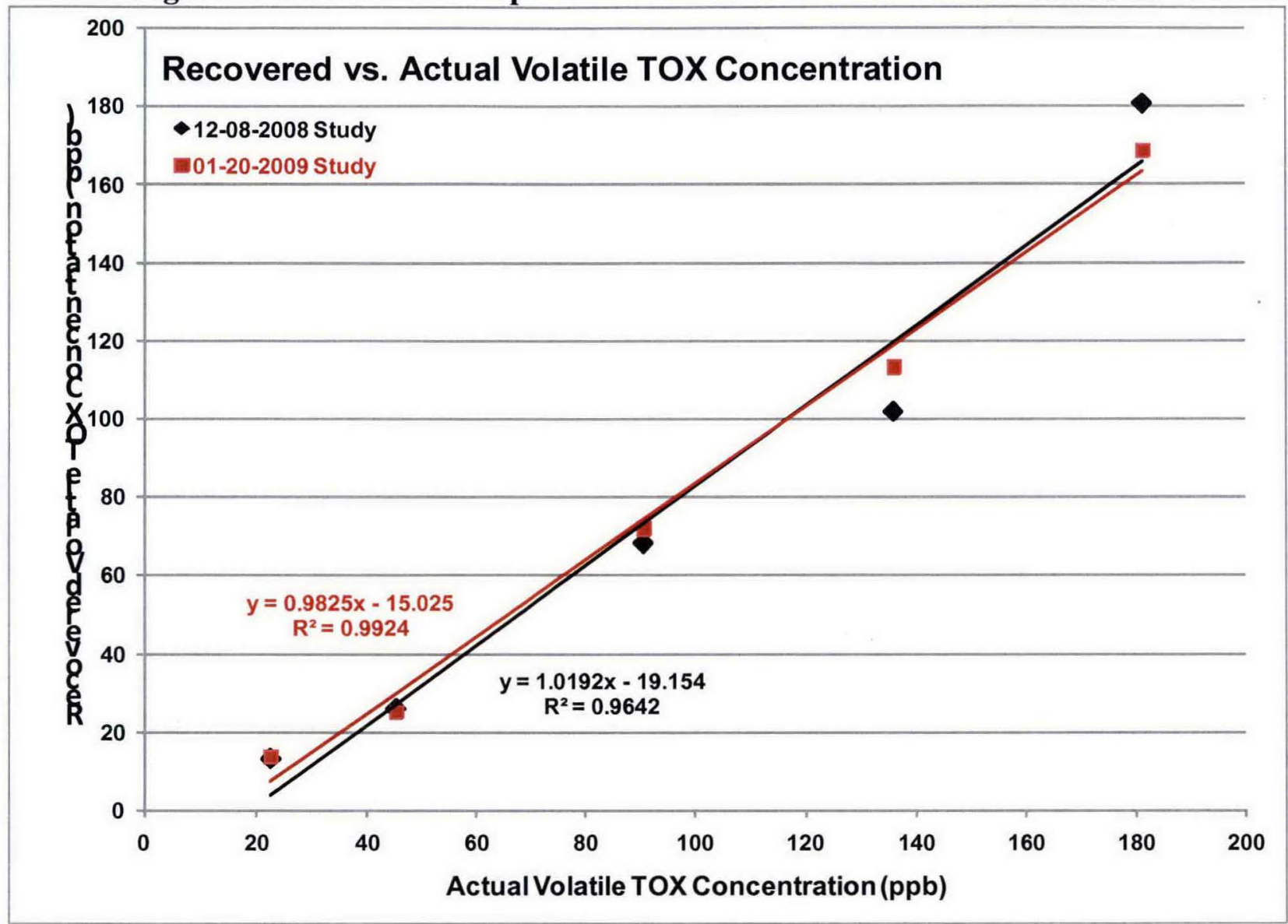

\subsection{TOX Method Detection Limit}

To demonstrate the stability and repeatability of the method and instrument, the method detection limit (MDL) was determined. To determine the MDL, a $15 \mathrm{ppb}$ TOX standard was prepared using 2,4,6-trichlorophenol in deionized water. Nine 100-mL aliquots of the standard were prepared using two adsorption tubes in series per WSCF procedure LA-523-444. Standard QC samples consisting of blanks and an LCS were run at the beginning of the analytical batch and an ICV standard at the end of the analytical batch. Table 7 presents the data for the MDL determination. 
Table 7. Method Detection Limit Determination Using 15 ppb TOX Standard ${ }^{1}$

\begin{tabular}{|c|c|c|c|c|c|c|c|c|c|c|c|c|}
\hline \multicolumn{7}{|c|}{ Run Number / Amount Recovered (ppb) } & $\begin{array}{c}\text { Avg. } \\
\text { (ppb) }\end{array}$ & $\begin{array}{c}\text { \% } \\
\text { Rec. }^{2}\end{array}$ & $\begin{array}{c}\text { Std. } \\
\text { Dev. }\end{array}$ & $\begin{array}{c}\text { MDL }^{\mathbf{3}} \\
\text { (ppb) }\end{array}$ \\
\hline $\mathbf{1}$ & $\mathbf{2}$ & $\mathbf{3}$ & $\mathbf{4}$ & $\mathbf{5}$ & $\mathbf{6}$ & $\mathbf{7}$ & $\mathbf{8}$ & $\mathbf{9}$ & \\
\hline 16.7 & 15.7 & 17.4 & 15.1 & 16.2 & 15.7 & 15.3 & 15.2 & 16.4 & 16.0 & $106 \%$ & 0.8 & 2.3 \\
\hline
\end{tabular}

Notes:

1 TOX standard $=15 \mathrm{ppb}$ TOX as 2,4,6-trichlorophenol in deionized water.

${ }^{2}$ Percent recovery $=100 \mathrm{x}$ amount recovered $/$ standard value of $15 \mathrm{ppb}$.

${ }^{3}$ Method detection limit $=\mathrm{t} x$ standard deviation where $\mathrm{t}=$ Student's $\mathrm{t}$ value for a two-tailed test at the $99 \%$ level with eight degrees of freedom $(t=2.90)$.

The MDL presented in Table 7 is $2.3 \mathrm{ppb}$ and is comparable to the MDLs obtained at other laboratories (Meznarich 2008). The MDL of $2.3 \mathrm{ppb}$ in the deionized water matrix indicates the method and instrument have good stability and repeatability. This MDL is about half the MDL of $5.1 \mathrm{ppb}$ calculated in Section 3.1.2 for a $10 \mathrm{ppb}$ TOX standard in a $100 \mathrm{ppm}$ inorganic chloride matrix.

\subsection{Sample Matrix as a Possible Cause of High TOX Recovery and High Adsorption Tube Breakthrough}

The results from a set of four samples analyzed on May 8, 2008, showed two samples with low TOX values and two with high TOX values. However, all four samples were collected within a few minutes, and the customer confirmed that all four samples came from the same sample point. Furthermore, the two samples with high TOX values tended to have higher apparent breakthrough of TOX from the top to the bottom adsorption tubes than the two samples with low TOX values. These four samples were selected to investigate any differences in the sample matrix that could explain why two samples showed low TOX values and two showed high TOX values and high breakthrough.

The TOX value for each sample was determined in triplicate using procedure LA-523-444, revision B-3 (WSCF 2007). After eluting $100 \mathrm{~mL}$ of the sample through the two adsorption tubes mounted in series, the tubes were rinsed with $6 \mathrm{~mL}$ of $10 \mathrm{~g} / \mathrm{L}$ potassium nitrate solution to remove residual inorganic chloride. Table 8 presents the data resulting from this analysis. 


\section{HNF-39194 Revision 1}

Table 8. Matrix Analysis Results for Four Replicate Samples

\begin{tabular}{|l|c|c|c|c|}
\hline \multicolumn{1}{|c|}{ Metric } & Sample 1 & Sample 2 & Sample 3 & Sample 4 \\
\hline WSCF Sample ID & W08P002067 & W08P002068 & W08P002069 & W08P002070 \\
\hline TOX results & 9.5 & 5.4 & 173 & 258 \\
(3 analyses, ppb) & 5.6 & 5.6 & 229 & 235 \\
& 6.7 & 3.9 & 190 & 205 \\
\hline TOX Percent $_{\text {Breakthrough }^{1}}^{33}$ & 31 & 27 & 41 & 46 \\
& 42 & 48 & 54 & 56 \\
\hline IC chloride (ppm) & 30.3 & 39 & 53 & 56 \\
\hline IC sulfate (ppm) & 773 & 29.4 & 30.7 & 31.3 \\
\hline TOC (ppm) & 0.4412 & 0.4632 & 806 & 800 \\
\hline VOA & All analytes & All analytes & All analytes & All analytes \\
& $<$ LOQ & $<$ LOQ & $<$ LOQ & $<$ LOQ \\
\hline
\end{tabular}

Notes:

${ }^{1}$ Percent breakthrough $=100 \times$ (TOX conc. in bottom adsorption tube) $/$ (sum of TOX conc. in top and bottom adsorption tubes).

The apparent TOX differences between the two samples with low TOX values (2067 and 2068), and the two samples with high TOX values (2069 and 2070) cannot be explained by any variations in the sample matrix as determined by this study:

- The ion-chromatography data show that the inorganic composition for chloride, nitrate, phosphate, and sulfate is similar in the four samples.

- The TOC values show little difference among the four samples.

- The VOA by EPA method 8260 (EPA 1996b) did not reveal any hits greater than the limit of quantitation for volatile organic species in the four samples.

One possible explanation for the anomalously high TOX results is that two of the four samples were accidentally field preserved with hydrochloric acid rather than sulfuric acid. The similarity of the sulfate and chloride concentrations in all four samples indicates that the samples were all field preserved with sulfuric acid and not hydrochloric acid.

\subsection{Effect of Inorganic Chloride on TOX Analyses}

The objective of this study was to determine at what level inorganic chloride interferes with the determination of TOX by method LA-523-444, revision B-3 (WSCF 2007). The approach used 


\section{HNF-39194 Revision 1}

was to generate a series of standards with a constant TOX (as 2,4,6-trichlorophenol) concentration and increasing amounts of inorganic chloride. Eleven standards each with a TOX concentration of $15 \mathrm{ppb}$ were spiked with an amount of inorganic chloride ranging from 0 to $500 \mathrm{ppm}$. After eluting each sample through two adsorption tubes connected in series, the tubes were washed with $6 \mathrm{~mL}$ of $10 \mathrm{~g} / \mathrm{L}$ potassium nitrate to remove inorganic chloride. The volume and concentration of nitrate wash were similar to those historically used for customer samples.

The TOX run sequence consisted of blanks, an LCS standard, and the standards in Table 9 run in the order shown in the table. Table 9 and Figure 5 and Figure 6 show the results of this study.

Table 9. Effect of Inorganic Chloride on the Recovery of 15 ppb TOX Standards ${ }^{1}$

\begin{tabular}{|c|c|c|c|c|}
\hline $\begin{array}{c}\text { Standard } \\
\text { Number }\end{array}$ & $\begin{array}{c}\text { Chloride Conc. } \\
\text { (ppm) }\end{array}$ & $\begin{array}{c}\text { TOX response } \\
\text { (ppb) }\end{array}$ & $\begin{array}{c}\text { Percent } \\
\text { Recovery }\end{array}$ & $\begin{array}{c}\text { Percent } \\
\text { Breakthrough }^{2}\end{array}$ \\
\hline Std. 1 & 0 & 17.3 & 115 & 100 \\
\hline Std. 2 & 0.5 & 17.5 & 116 & 2 \\
\hline Std. 3 & 1 & 16.6 & 111 & 9 \\
\hline Std. 4 & 2 & 17.8 & 119 & 0 \\
\hline Std. 5 & 5 & 15.1 & 101 & 9 \\
\hline Std. 6 & 10 & 19.2 & 128 & 10 \\
\hline Std. 7 & 20 & 25.9 & 172 & 23 \\
\hline Std. 8 & 50 & 32.9 & 219 & 29 \\
\hline Std. 9 & 100 & 52.5 & 350 & 26 \\
\hline Std. 10 & 200 & 39.5 & 263 & 33 \\
\hline Std. 11 & 500 & 48.0 & 320 & \\
\hline
\end{tabular}

Notes:

${ }^{1}$ Standards were made from 2,4,6-trichlorophenol stock standards in deionized water and were acidified with $0.5 \mathrm{~mL}$ concentrated sulfuric acid per liter of standard; chloride was added as sodium chloride.

${ }^{2}$ Percent breakthrough $=100 \times$ (TOX conc. in bottom adsorption tube) / (sum of TOX conc. in top and bottom adsorption tubes) 


\section{HNF-39194 Revision 1}

Figure 5. Effect of Inorganic Chloride on the Recovery of 15 ppb TOX Standards

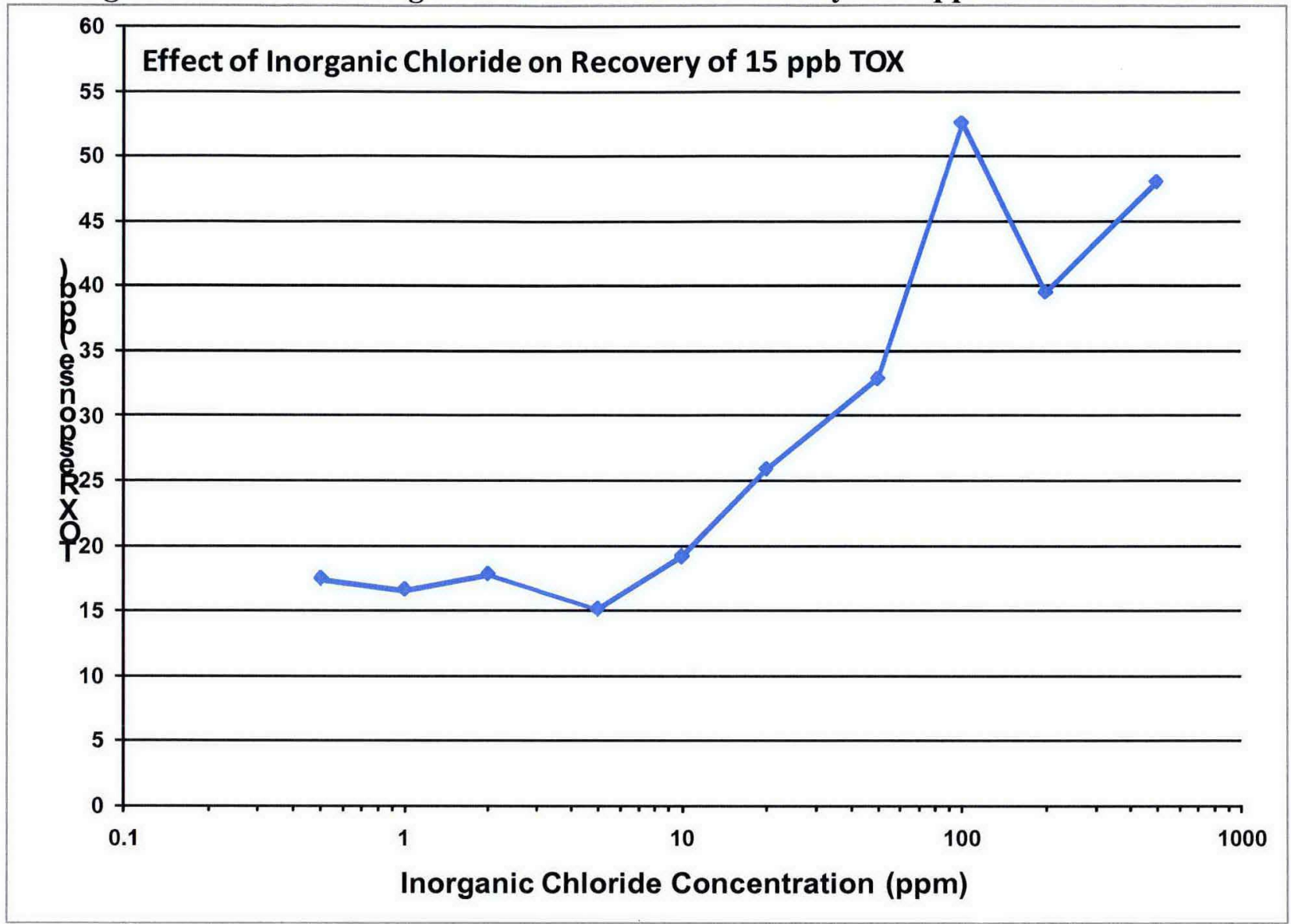




\section{HNF-39194 Revision 1}

Figure 6. Effect of Inorganic Chloride on Percent Breakthrough of 15 ppb TOX

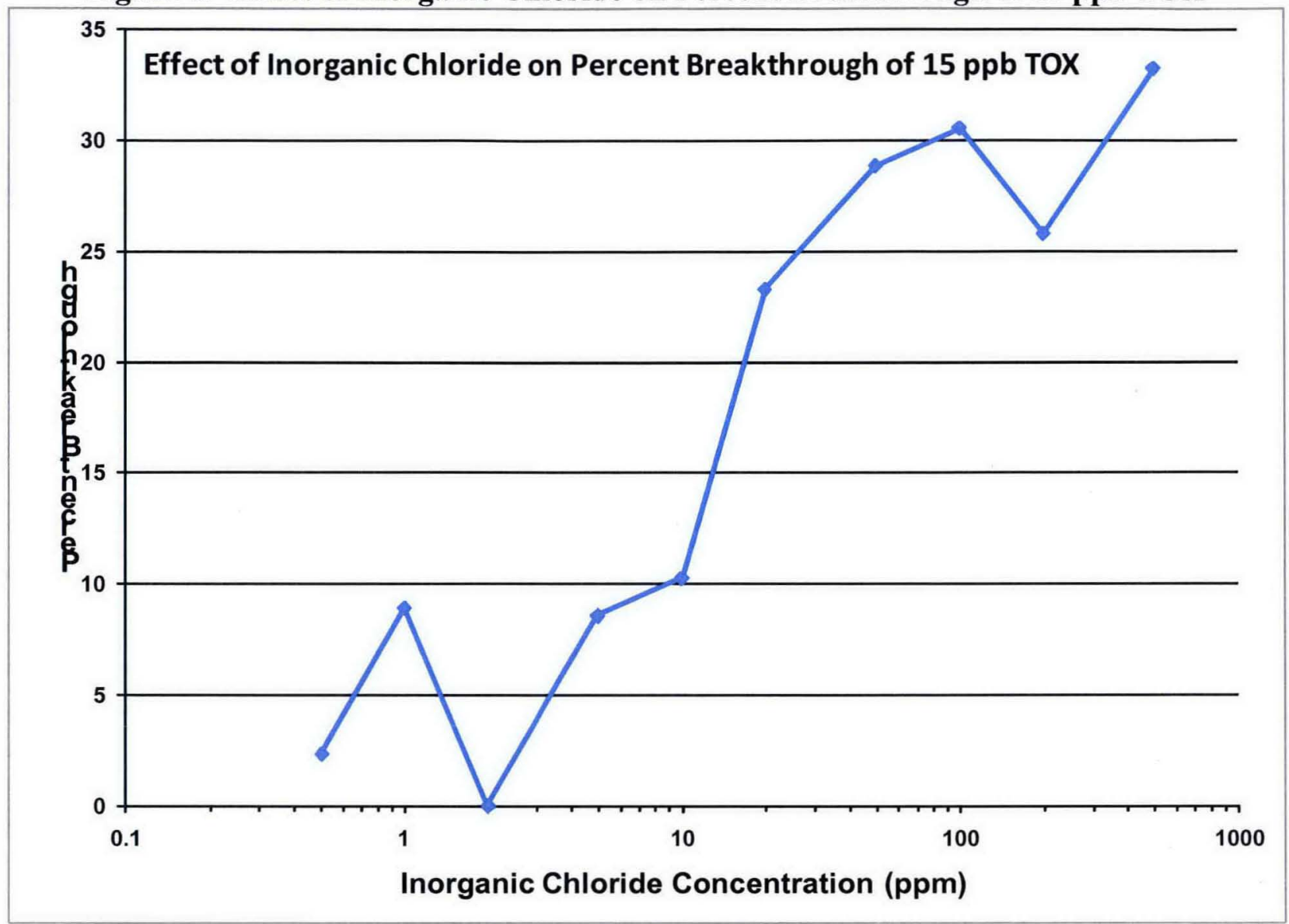

The conclusions from this study are:

- Inorganic chloride does not affect the TOX up to about 5 to $10 \mathrm{ppm}$ chloride but then shows a strong increase in the TOX response with higher inorganic chloride concentration.

- Inorganic chloride concentrations greater than $5 \mathrm{ppm}$ also lead to an increase in the apparent breakthrough to the second adsorption tube.

- With the nitrate wash used in this study, inorganic chloride interferes with the TOX analysis at about 700 times the TOX concentration. The EPA 9020B method claims no interference up to 20,000 times the TOX concentration (EPA 1996a). (The nitrate wash for this study was $6 \mathrm{~mL}$ of $10 \mathrm{~g} / \mathrm{L}$ potassium nitrate).

- The chloride concentration in typical Hanford groundwater varies from 9 to $70 \mathrm{ppm}$ (Anastos 2008b). Hence, the inorganic chloride concentration in Hanford groundwater samples is within the range that may explain the erroneously elevated TOX results and high adsorption tube breakthrough. 


\section{HNF-39194 Revision 1}

\subsection{Effect of Nitrate Wash Concentration and Volume on Removal of Inorganic Chloride}

Procedure LA-523-444, Revision B-3, requires that sample-loaded adsorption tubes be washed with $3 \mathrm{~mL}$ of $10 \mathrm{~g} / \mathrm{L}$ potassium nitrate solution to remove inorganic chloride from the tubes prior to analysis (WSFC 2007). This wash volume is an increase from the $2 \mathrm{~mL}$ nitrate wash volume recommended in EPA procedure 9020B (EPA 1996a). The manual for the Euroglas 3000 TOX analyzer recommends that the samples be washed with $25 \mathrm{~mL}$ of acidified $0.7 \mathrm{~g} / \mathrm{L}$ nitrate solution followed by $25 \mathrm{~mL}$ of deionized water (Thermo Euroglas 2001).

Previous tests established that inorganic chloride concentrations greater than 5 to $10 \mathrm{ppm}$ cause anomalously high recoveries of TOX and increased apparent breakthrough into the second adsorption tube (Section 3.4). The tests described in this section are designed to determine the optimum concentration and volume of nitrate rinse required to remove inorganic chloride from the sample.

To determine a nitrate wash scheme optimal for removing the inorganic chloride interference, the following tests were performed. A $15 \mathrm{ppb}$ TOX (as 2,4,6-trichlorophenol) standard was prepared in deionized water with a matrix of $100 \mathrm{ppm}$ inorganic chloride (as sodium chloride) and acidified with $0.5 \mathrm{~mL}$ concentrated sulfuric acid per liter of standard. For each nitrate wash treatment, $100 \mathrm{~mL}$ of this TOX standard was eluted through two adsorption tubes in series. After eluting the sample through the adsorption tubes, the tubes were eluted with one of nine wash treatments. Each test was performed in triplicate. The wash treatments and results are outlined in Table 10 and presented in Figure 7. 


\section{HNF-39194 Revision 1}

Table 10. Effect of Nitrate Wash Treatments on the Recovery of 15 ppb TOX Standards ${ }^{1}$

\begin{tabular}{|c|c|c|c|c|}
\hline $\begin{array}{c}\text { Treatment } \\
\text { Number }\end{array}$ & $\begin{array}{c}\text { Nitrate Wash } \\
\text { Treatment }\end{array}$ & $\begin{array}{c}\text { Follow-up DI } \\
\text { Water Rinse } \\
\text { Volume (mL) }\end{array}$ & $\begin{array}{c}\text { Average TOX } \\
\text { Recovery } \\
\text { (ppb) }\end{array}$ & $\begin{array}{c}\text { Percent } \\
\text { Recovery }\end{array}$ \\
\hline 1 & $6 \mathrm{~mL} 10 \mathrm{~g} / \mathrm{L} \mathrm{KNO}_{3}$ & 0 & 49.3 & 329 \\
\hline 2 & $10 \mathrm{~mL} 10 \mathrm{~g} / \mathrm{L} \mathrm{KNO}_{3}$ & 0 & 43.8 & 292 \\
\hline 3 & $25 \mathrm{~mL} 10 \mathrm{~g} / \mathrm{L} \mathrm{KNO}_{3}$ & 25 & 34.6 & 230 \\
\hline 4 & $6 \mathrm{~mL} 50 \mathrm{~g} / \mathrm{L} \mathrm{KNO}_{3}$ & 2 & 20.7 & 138 \\
\hline 5 & $10 \mathrm{~mL} 50 \mathrm{~g} / \mathrm{L} \mathrm{KNO}_{3}$ & 2 & 27.0 & 180 \\
\hline 6 & $25 \mathrm{~mL} 50 \mathrm{~g} / \mathrm{L} \mathrm{KNO}_{3}$ & 25 & 24.6 & 164 \\
\hline 7 & $6 \mathrm{~mL} 100 \mathrm{~g} / \mathrm{L} \mathrm{KNO}_{3}$ & 6 & 24.2 & 161 \\
\hline 8 & $10 \mathrm{~mL} 100 \mathrm{~g} / \mathrm{L} \mathrm{KNO}_{3}$ & 6 & 20.8 & 138 \\
\hline 9 & $25 \mathrm{~mL} 100 \mathrm{~g} / \mathrm{L} \mathrm{KNO}_{3}$ & 25 & 25.7 & 171 \\
\hline
\end{tabular}

Notes:

${ }^{1}$ Standards were $100 \mathrm{~mL}$ of $15 \mathrm{ppb}$ TOX as 2,4,6-trichlorophenol in aqueous $100 \mathrm{ppm}$ chloride as sodium chloride and acidified with $0.5 \mathrm{~mL}$ concentrated sulfuric acid per liter of standard.

2 Average of three determinations at each treatment. 
Figure 7. Effect of Nitrate Wash Treatments on the Recovery of 15 ppb TOX Standards

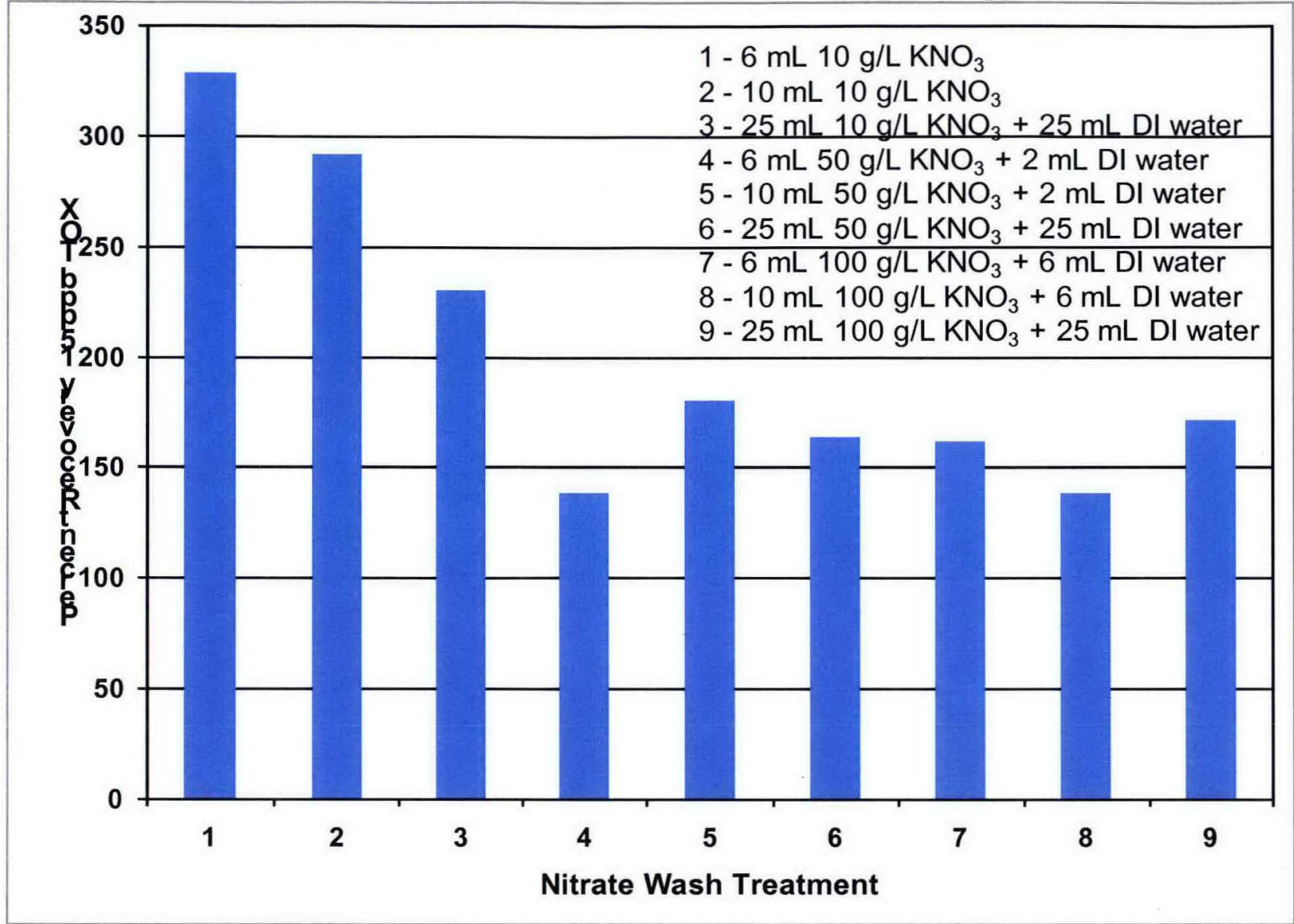

The observations from these test results are:

- Increasing the wash volume appears to reduce the inorganic chloride contribution to the TOX results.

- Increasing the nitrate concentration in the wash solution from $10 \mathrm{~g} / \mathrm{L}$ to $50 \mathrm{~g} / \mathrm{L}$ potassium nitrate appears to reduce the inorganic chloride contribution in the TOX analysis.

- Increasing the potassium nitrate concentration to $100 \mathrm{~g} / \mathrm{L}$ potassium nitrate yields results similar to those for the $50 \mathrm{~g} / \mathrm{L}$ wash solution.

The minimum recovery of 138 percent may be caused by residual inorganic chloride in the deionized water and potassium nitrate. The $100 \mathrm{~mL}$ water blank contributes about 2 to $3 \mu \mathrm{g}$ to the result (up to 20 percent). The potassium nitrate used is 99.5 percent pure and may also contribute some inorganic chloride to the sample result.

In conclusion, rinses with larger wash volumes and higher nitrate concentrations appear to reduce interferences from inorganic chloride in the sample matrix. 


\section{HNF-39194 Revision 1}

\subsection{Effect of Purge Time During Sample Preparation on TOX Analyses}

We observed that for a set of four replicate samples, samples analyzed later in the day often had higher TOX values than sibling samples run earlier in the day. If the samples with high TOX values were subsequently rerun earlier on another day, the rerun TOX values were typically lower and comparable to the original TOX results of the sibling samples. One example of this behavior is shown in Table 11.

Table 11. Effect of Analysis Time on TOX Analytical Results for Replicate Samples

\begin{tabular}{|c|c|c|c|c|}
\hline Metric & Sample 1 & Sample 2 & Sample 3 & Sample 4 \\
\hline WSCF Sample ID & W08P002855 & W08P002856 & W08P002857 & W08P002858 \\
\hline \multicolumn{5}{|c|}{ Initial TOX Results: } \\
\hline $\begin{array}{l}\text { Initial TOX results } \\
(3 \text { analyses, ppb) }\end{array}$ & $\begin{array}{l}<5 \\
<5 \\
<5\end{array}$ & $\begin{array}{l}<5 \\
<5 \\
<5\end{array}$ & $\begin{array}{c}24.7 \\
34.8 \\
7.1\end{array}$ & $\begin{array}{l}7.3 \\
7.1 \\
5.3\end{array}$ \\
\hline $\begin{array}{l}\text { Initial Analysis } \\
\text { Date and Times }{ }^{1}\end{array}$ & $\begin{array}{c}7 / 1 / 08 \\
10: 46,10: 58 \\
11: 10,11: 23 \\
11: 35,11: 47\end{array}$ & $\begin{array}{c}7 / 1 / 08 \\
13: 12,13: 24 \\
13: 37,13: 49 \\
14: 01,14: 14\end{array}$ & $\begin{array}{c}7 / 1 / 08 \\
14: 30,14: 43 \\
14: 55,15: 07 \\
15: 19,15: 32\end{array}$ & $\begin{array}{c}7 / 1 / 08 \\
15: 47,16: 00 \\
16: 12,16: 24 \\
16: 37,16: 49\end{array}$ \\
\hline \multicolumn{5}{|c|}{ Rerun TOX Results: } \\
\hline $\begin{array}{l}\text { Rerun TOX results } \\
(3 \text { analyses, ppb) }\end{array}$ & $\mathrm{n} / \mathrm{a}$ & $\mathrm{n} / \mathrm{a}$ & $\begin{array}{l}5.2 \\
<5 \\
<5\end{array}$ & $\begin{array}{l}<5 \\
<5 \\
<5\end{array}$ \\
\hline $\begin{array}{l}\text { Rerun Analysis } \\
\text { Date and Times }{ }^{1}\end{array}$ & $\mathrm{n} / \mathrm{a}$ & $\mathrm{n} / \mathrm{a}$ & $\begin{array}{c}7 / 2 / 08 \\
10: 29,10: 41 \\
10: 54,11: 06 \\
11: 18,11: 30\end{array}$ & $\begin{array}{c}7 / 2 / 08 \\
11: 42,11: 54 \\
12: 06,12: 18 \\
12: 31,12: 43\end{array}$ \\
\hline
\end{tabular}

Notes:

${ }^{1}$ Times listed are in pairs; the first time listed is for the top adsorption tube, and the second time listed is for the bottom adsorption tube. The three lines of times for each sample represent the first, second, and third analytical replicates for each sample.

Further investigation revealed that on July 1, samples W08P002855 and W08002856 were prepped early in the day together with the batch QC samples. The adsorption tubes for these two samples were eluted with the nitrate wash almost immediately after completing sample elution through the adsorption tubes. However, samples W08P002857 and W08P002858 were loaded into the sample preparation reservoirs before lunch and allowed to elute through the adsorption tubes over the lunch break. After sample elution, the oxygen pressurization gas continued to purge through the adsorption tubes for up to 90 minutes before the tubes were eluted with nitrate 


\section{HNF-39194 Revision 1}

wash to eliminate inorganic chloride. These results suggest that allowing the adsorption tubes to purge with the pressurization gas for a prolonged time prior to eluting the tubes with the nitrate wash may lead to spuriously high TOX results. A likely explanation for this behavior is that the pressurization gas facilitates channeling through the activated carbon bed as the bed dries out. When the nitrate wash is applied, the wash follows the channeling and does not effectively remove inorganic chloride from the carbon bed.

To study the possible effect of gas purge time on TOX results, a simple study was performed to compare the TOX results for two test samples prepared with no purge time and with a 90-minute purge time before applying the nitrate wash. One test sample was a TOX standard consisting of $15 \mathrm{ppb}$ TOX (as 2,4,6-trichlorophenol) in a matrix of $50 \mathrm{ppm}$ chloride (as sodium chloride) acidified with $0.5 \mathrm{~mL}$ sulfuric acid per liter of standard. The second test sample was groundwater sample W08P002068; this sample was one of four groundwater field replicates with inconsistent TOX results (see Table 8).

The standard and the groundwater sample were each run in triplicate at the two treatments of zero purge time and 90-minute purge time prior to the nitrate wash. The nitrate wash solution was $6 \mathrm{~mL}$ of $10 \mathrm{~g} / \mathrm{L}$ potassium nitrate. Sample preparation and analysis incorporated routine QC samples consisting of blanks, an LCS, and an ICV. Table 12 lists the results of these tests.

Table 12. Results from Sample Preparation Purge Tests

\begin{tabular}{|c|c|c|c|c|c|c|}
\hline \multirow[b]{4}{*}{ Sample } & \multicolumn{6}{|c|}{ Results } \\
\hline & \multicolumn{3}{|c|}{ No Purge } & \multicolumn{3}{|c|}{ 90-Minute Purge } \\
\hline & \multirow{2}{*}{$\begin{array}{l}\text { TOX } \\
\text { (ppb) }\end{array}$} & \multirow{2}{*}{$\begin{array}{l}\text { Percent } \\
\text { Break- } \\
\text { through }^{1}\end{array}$} & $\begin{array}{c}\text { Average } \\
\text { (ppb) }\end{array}$ & \multirow{2}{*}{$\begin{array}{l}\text { TOX } \\
\text { (ppb) }\end{array}$} & \multirow{2}{*}{$\begin{array}{l}\text { Percent } \\
\text { Break- } \\
\text { through }\end{array}$} & $\begin{array}{c}\text { Average } \\
\text { (ppb) }\end{array}$ \\
\hline & & & $\% \mathrm{RSD}^{2}$ & & & $\%$ RSD $^{2}$ \\
\hline \multirow{3}{*}{$\begin{array}{l}\text { TOX } \\
\text { Standard }{ }^{3} \\
(15 \text { ppb TOX) }\end{array}$} & 37.9 & 27 & \multirow{2}{*}{34.6} & 44.5 & 21 & \multirow{2}{*}{35.4} \\
\hline & 33.1 & 25 & & 34.3 & 26 & \\
\hline & 32.6 & 24 & $8.5 \%$ & 27.4 & 25 & $24.4 \%$ \\
\hline \multirow{3}{*}{$\begin{array}{l}\text { Sample }^{4} \\
\text { (W08P002068) }\end{array}$} & 7.6 & 73 & \multirow{2}{*}{6.0} & 17.1 & 35 & \multirow{2}{*}{10.9} \\
\hline & 5.1 & 37 & & 9.4 & 28 & \\
\hline & 5.2 & 39 & $23.7 \%$ & 6.2 & 42 & $51.4 \%$ \\
\hline
\end{tabular}

Notes:

${ }^{1}$ Percent breakthrough $=100 \mathrm{x}$ (TOX conc. in bottom adsorption tube) $/$ (sum of TOX conc. in top and bottom adsorption tubes)

${ }^{2}$ Percent relative standard deviation $=100 \mathrm{x}$ standard deviation of measurements / average of measurements

${ }^{3}$ TOX standard consisted of $15 \mathrm{ppb}$ TOX (as 2,4,6-trichlorophenol) in a matrix of $50 \mathrm{ppm}$ chloride (as sodium chloride) acidified with $0.5 \mathrm{~mL}$ concentrated sulfuric acid per liter of standard.

${ }^{4}$ Originally reported average value for this sample was $<5$ ppb TOX. 


\section{HNF-39194 Revision 1}

The data in Table 12 indicate that the samples treated with no purge time yield results with better precision than those samples treated with the 90-minute purge time. This could indicate that excessive purging does occasionally create channeling that reduces the amount of inorganic chloride removed during the wash step and thus leads to spuriously high TOX values. As a result of this observation, a note will be added to the TOX procedure to eliminate excessive purging of the adsorption tubes prior to the nitrate wash step.

Recoveries for the $15 \mathrm{ppb}$ TOX standard were undoubtedly high because the wash procedure with $6 \mathrm{~mL}$ of $10 \mathrm{~g} / \mathrm{L}$ potassium nitrate is not as effective as wash procedures with more concentrated nitrate solutions.

\subsection{Effect of Sulfites on TOX Analyses}

Environmental Protection Agency SW-846 method 9020B recommends that $5 \mathrm{mg}$ of sodium sulfite be added per liter of sample if the sample, such as municipal tap water, contains free chlorine (EPA 1996a). The practice at WSCF has been to add a few milligrams of crystalline sodium bisulfite to each sample bottle. Sodium bisulfite is added when the sample bottles are first brought into the laboratory and dissolves quickly in water samples without stirring.

Sodium sulfite and sodium bisulfite are both mild reducing agents used to remove chlorine. The effect of these treatments on TOX recovery is unknown. To investigate possible effects of sodium bisulfite on TOX recovery, two tests were performed. The first test involved three different sodium bisulfite treatments of well water provided by the Pacific Northwest National Laboratory groundwater program. The second test consisted of comparing the results of customer-supplied samples analyzed before and after treatment with sodium bisulfite.

For the groundwater test, the three treatments consisted of:

1. Perform TOX analysis of untreated well water.

2. Perform TOX analysis of well water treated with a few milligrams of sodium bisulfite per $500 \mathrm{~mL}$ of well water.

3. Perform TOX analysis of well water treated with 5 grams of sodium bisulfite per $500 \mathrm{~mL}$ of well water.

For each treatment, 100-mL aliquots of well water were prepared and analyzed for TOX in triplicate. Samples were eluted through two adsorption tubes in series followed by a wash of $6 \mathrm{~mL}$ of $10 \mathrm{~g} / \mathrm{L}$ potassium nitrate solution. The treatment with 5 grams of sodium bisulfite is a much larger dose of sodium bisulfite than normally used and should hopefully accentuate any effects sodium bisulfite might have on the TOX analysis. Table 13 presents the results of these tests.

The second test simply compared the TOX results of a number of customer-supplied groundwater samples before and after treatment with a few milligrams of sodium bisulfite. The 


\section{HNF-39194 Revision 1}

samples were analyzed per WSCF TOX procedure LA-523-444, revision B-3 (WSCF 2007). Table 14 shows the results of this comparison.

Table 13. Effect of Sodium Bisulfite on TOX Results

\begin{tabular}{|c|c|c|}
\hline Treatment $^{1}$ & TOX Results $^{\mathbf{2}}$ (ppb) & Average TOX (ppb) $^{\text {Tod }}$ \\
\hline Treatment 1 & $7.11,6.75,7.46$ & 7.11 \\
\hline Treatment 2 & $<5,<5,<5$ & $<5$ \\
\hline Treatment 3 & $<5,<5,<5$ & $<5$ \\
\hline
\end{tabular}

Notes:

${ }^{1}$ Treatment $1=$ groundwater sample with no added sodium bisulfite; Treatment $2=$ groundwater sample with a few milligrams of sodium bisulfite per $500-\mathrm{mL}$ sample; Treatment 3 = groundwater sample with 5 grams of sodium bisulfite per 500-mL sample.

${ }^{2}$ All three results for the triplicate analysis of each sample are shown.

Table 14. Comparison of TOX Results Without and With Bisulfite Treatment

\begin{tabular}{|c|c|c|c|}
\hline Sample & $\begin{array}{c}\text { Average TOX } \\
\text { Without Bisulfite } \\
\text { (ppb) }\end{array}$ & $\begin{array}{c}\text { Average TOX With } \\
\text { Bisulfite } \\
\text { (ppb) }\end{array}$ & $\begin{array}{c}\text { RPD }^{\mathbf{1}} \\
\text { Without and With } \\
\text { Bisulfite (\%) }\end{array}$ \\
\hline W08P002697 & 88.5 & 59.0 & 40 \\
\hline W08P002716 & 13.6 & 13.1 & 4 \\
\hline W08P002717 & 14.5 & 13.3 & 9 \\
\hline W08P002718 & 15.5 & 14.9 & 4 \\
\hline W08P002719 & 14.9 & 13.3 & 11 \\
\hline
\end{tabular}

Notes:

$100 \times$ laverage TOX without bisulfite - average TOX with bisulfite

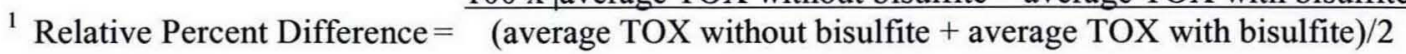

The results in Table 13 and Table 14 seem to indicate that the bisulfite treatment may indeed reduce the apparent TOX value in groundwater samples. However, groundwater samples are not likely to contain residual chlorine. Another likely explanation for the apparent effect of bisulfite is that the groundwater samples contain volatile TOX species; some of the TOX volatiles were likely lost to the headspace after the initial analysis without the bisulfite treatment and before subsequent analysis with the bisulfite treatment. 


\section{HNF-39194 Revision 1}

In any event, residual inorganic chlorine is not likely to be present in groundwater samples, and therefore the practice of routinely dosing groundwater samples with bisulfite prior to analysis will be discontinued.

\subsection{References}

Anastos, 2008a, "Total Organic Halides-WSCF Sample \#W08P000971 (B1RYV1)," Memorandum SGW-HLA-005 from H. L. Anastos to S. L. Fitzgerald, April 2, Fluor Hanford, Richland, Washington.

Anastos, 2008b, “TOX Test Plan Suggestions," email from H. L. Anastos to H. K. Meznarich, April 5, Fluor Hanford, Richland, Washington.

EPA, 1996a, "Total Organic Halides (TOX)," Method 9020B, Rev. 2, in Test Methods for Evaluating Solid Waste: Physical/Chemical Methods, SW-846, Rev. 3, U. S.

Environmental Protection Agency, Washington D.C..

EPA, 1996b, "Volatile Organic Compounds by Gas Chromatography/Mass Spectrometry (GC/MS)," Method 8260B, Rev. 2, in Test Methods for Evaluating Solid Waste:

Physical/Chemical Methods, SW-846, Rev. 3, U.S. Environmental Protection Agency, Washington D.C..

Meznarich, 2008, Private communication, H. K. Meznarich to M. Stauffer.

Thermo Euroglas, 2001, Thermo Euroglas ECS 3000 User Manual, English version 3.0, November 2001, Thermo Euroglas B. V., Delft, Netherlands.

WSCF, 2007, Total Organic Halides Based on SW-846 Method 9020B, Method LA-523-444, Revision B-3, Waste Sampling and Characterization Facility, Fluor Hanford, Richland, Washington. 